\title{
Development of the real-time RT-PCR technique for the detection of Soil-borne wheat mosaic virus (SBWMV)
}

\section{Zastosowanie techniki real-time RT-PCR w diagnostyce wirusa odglebowej mozaiki pszenicy (Soil-borne wheat mosaic virus, SBWMV)}

\author{
Katarzyna Trzmiel*, Małgorzata Jeżewska
}

\begin{abstract}
Summary
Soil-borne wheat mosaic virus (SBWMV) was detected in Poland for the first time in 2010 in the Southern Greater Poland and in the following years in the Lower Silesia and in the Pomerania regions. All found isolates induced mild symptoms of disease. Stunting without typical leaf mosaic of infected plants was observed. A low concentration of the virus in plant sap caused troubles in diagnostics. Difficulties in interpreting of obtained ambiguous results of ELISA test and RT-PCR technique were the main problem. The specific primers and real-time RT-PCR conditions were developed to improve sensitivity and of this assay for the detection of SBWMV. It can be used when the virus concentration in infected plants is very low and the standard ELISA test and RT-PCR technique failed.
\end{abstract}

Key words: SBWMV; real-time RT-PCR; detection

\section{Streszczenie}

Wirus odglebowej mozaiki pszenicy (Soil-borne wheat mosaic virus, SBWMV) wykryto w Polsce po raz pierwszy w 2010 roku, w południowej Wielkopolsce, a w kolejnych latach na Dolnym Śląsku i na Pomorzu. Wszystkie wykryte izolaty powodowały łagodny przebieg choroby. Obserwowano jedynie zahamowanie wzrostu chorych roślin bez typowych objawów mozaiki liści. Niska koncentracja cząstek wirusowych w soku porażonych roślin powodowała kłopoty w diagnostyce. Główny problem polegał na trudnościach w interpretacji otrzymywanych często niejednoznacznych wyników zastosowanego testu ELISA oraz techniki RT-PCR (reverse transcription - polymerase chain reaction). Dzięki opracowaniu specyficznych starterów oraz warunków przebiegu reakcji odwrotnej transkrypcji i łańcuchowej polimerazy w czasie rzeczywistym (real-time RT-PCR) wykazano przydatność tej techniki do wykrywania SBWMV i do weryfikacji wątpliwych wyników.

Słowa kluczowe: SBWMV; real-time RT-PCR; wykrywanie

Instytut Ochrony Roślin - Państwowy Instytut Badawczy

Zakład Wirusologii i Bakteriologii

Władysława Węgorka 20, 60-318 Poznań

*corresponding author: K.Trzmiel@iorpib.poznan.pl 


\section{Wstęp / Introduction}

Wirus odglebowej mozaiki pszenicy (Soil-borne wheat mosaic virus, SBWMV) należy do rodzaju Furovirus w rodzinie Virgaviridae. SBWMV wykryto po raz pierwszy w roku 1923 w centralnej części USA (Verchot-Lubicz 2004), a w Europie jego obecność potwierdzono w Niemczech (Koening i Huth 2003) i w Polsce (Trzmiel i wsp. 2012). Wirus przenosi się przez pierwotniaka glebowego Polymyxa graminis Led. porażającego liczne gatunki z rodziny Poaceae, stanowiąc szczególne zagrożenie dla form ozimych żyta, pszenżyta i pszenicy. Typowe objawy choroby to: mozaika liści, zahamowanie wzrostu oraz obniżenie plonu porażonych roślin (Verchot-Lubicz 2004).

Polskie izolaty SBWMV w przeciwieństwie do niemieckich wywołują jedynie łagodne i mało specyficzne objawy zahamowania wzrostu porażonych roślin. SBWMV występuje w niskiej koncentracji w tkankach chorych roślin, co powoduje liczne trudności w diagnostyce.

Celem pracy było opracowanie czułej i wiarygodnej molekularnej techniki diagnostycznej real-time RT-PCR (reverse transcription - polymerase chain reaction) weryfikującej często niejednoznaczne wyniki testu DAS-ELISA (double antibody sandwitch enzyme-linked immunosorbent assay) i techniki RT-PCR.

\section{Materiały i metody / Materials and methods}

Materiał badawczy stanowiły cztery izolaty SBWMV pochodzące $\mathrm{z}$ roślin pszenżyta, z objawami lekkiego skarłowacenia, zebrane podczas obserwacji polowych w 2012 roku, w Choryni (SBWMV-CH), Szelejewie (SBWMVSze) i w Stążkach (SBWMV-Pom, SBWMV-Pom2). Jako kontrolę pozytywną reakcji wykorzystywano niemiecki izolat „Heddeshein”-Baden-Wüsthernberg (zdiagnozowany jako SBWMV-De1), otrzymany jako materiał referencyjny z Julius Kühn-Institut Federal Research Centre for Cultivated Plants, natomiast kontrolę negatywną tworzyły próby bez matrycy.

Całkowity RNA z wytypowanych do badań roślin izolowano przy użyciu zestawu NucleoSpin RNA Plant firmy Macherey-Nagel (Niemcy) zgodnie z procedura dostarczoną przez producenta.

Amplifikację DNA prowadzono z użyciem własnej, zaprojektowanej na potrzeby niniejszych badań, pary starterów: SBWkrF /SBWkrR, odpowiednio (5'-TGCTTAAT GGCGTGAGTAAA-3') i (5'-TCGGTCTGACCCTGTT CTTC-3'), komplementarnych do fragmentu (od 482 do $728 \mathrm{nt}$ ) sekwencji kodującej białko płaszcza (coat protein CP) polskiego izolatu SBWMV-Poll (JQ231227). Do projektowania starterów wykorzystano program Primer3 (http://frodo.wi.mit.edu/primer3) (Rosen i Skaletski 2000).

W reakcji RT-PCR w czasie rzeczywistym używano zestawu Brilliant II SYBR Green QRT-PCR master mix, 1-Step firmy Stratagene (USA). Mieszaninę reakcyjną o końcowej objętości $25 \mu \mathrm{l}$ przygotowywano zgodnie $\mathrm{z}$ zaleceniami producenta. Reakcję prowadzono w aparacie Mx3005P Real-Time PCR system (Stratagene), w następujących warunkach termicznych: odwrotna transkrypcja przez 30 min $\mathrm{w} 50^{\circ} \mathrm{C}$, dezaktywakcja transkryptazy i jednoczesna aktywacja polimerazy HotStar Taq DNA w $95^{\circ} \mathrm{C}$ przez $10 \mathrm{~min}, 40$ cykli (denaturacja: $95^{\circ} \mathrm{C}$ przez $30 \mathrm{~s}$, przyłączanie starterów $\mathrm{w} 55^{\circ} \mathrm{C}$ przez $30 \mathrm{~s}$, elongacja $\mathrm{w} 72^{\circ} \mathrm{C}$ przez $30 \mathrm{~s}$ ). Specyficzność reakcji oznaczano przez analizę krzywej topnienia wyznaczanej w przedziale temperatur od 70 do $95^{\circ} \mathrm{C}$ i określenie temperatury topnienia $\left(T_{m}\right)$ uzyskanego produktu. Czułość reakcji wyznaczono przez szereg dziesiętnych rozcieńczeń tRNA SBWMV-De1 stosowanych jako matryca reakcji. Dodatkowe sprawdzanie specyficzności tej techniki prowadzono przez rozdział elektroforetyczny uzyskanych produktów w $1 \%$ żelu agarozowym z dodatkiem barwnika Midori Green (NIPPON Genetics Europe GmbH, Niemcy). Otrzymane produkty reakcji poddawano sekwencjonowaniu, a uzyskane sekwencje nukleotydów porównywano $\mathrm{z}$ sekwencjami nukleotydów izolatów: SBWMV-Poll (JQ231227), SBWMV-De1 (AF519799) i SBWMV-US-Nebraska (L07938), dostępnych w Banku Genów.

\section{Wyniki i dyskusja / Results and discussion}

Ocena zakresu wykrywania SBWMV w soku porażonych roślin wykazała zdolność wykrywania do 40 pg RNA wirusa (rys. 1). Optymalizacja warunków reakcji real-time RT-PCR z użyciem zaprojektowanej pary starterów umożliwiła wykrycie wszystkich polskich izolatów wirusa. Wyniki potwierdziły niższą koncentrację rodzimych izolatów SBWMV w stosunku do niemieckiego izolatu SBWMV-De1 użytego jako K+ (rys. 2). Analiza krzywej dysocjacji, jak i rozdział elektroforetyczny mieszaniny reakcyjnej wykazały obecność pojedynczego produktu reakcji o przewidywanej wielkości 246 pz (rys. 3, 4). Stwierdzono równe wartości $\mathrm{T}_{\mathrm{m}}$ dla badanych izolatów SBWMV $\left(82,1^{\circ} \mathrm{C}\right)$. Dodatkowa ocena sekwencji nukleotydów uzyskanych produktów reakcji RT-PCR potwierdziła ich identyczność (rys. 5).

Real-time RT-PCR jest bardzo czułą i specyficzną techniką, powszechnie stosowaną w diagnostyce chorób wirusowych zbóż (Price i wsp. 2010; Zhang i wsp. 2010). Opublikowane dane (Ratti i wsp. 2004) wskazują, że technika real-time RT-PCR jest dziesięć razy czulsza i szybsza od standardowej techniki RT-PCR, ponieważ nie wymaga elektroforetycznego rozdziału powstałych produktów reakcji w żelu agarozowym ani sekwencjonowania w celu sprawdzenia specyficzności uzyskanej sekwencji nukleotydów. Zaprezentowana technika real-time RT-PCR z użyciem zaprojektowanej pary starterów SBWkr-F/ SBWkr-R po raz pierwszy umożliwia specyficzne wykrywanie SBWMV i może być wykorzystywana w badaniach nad występowaniem SBWMV w Europie. Według nowej klasyfikacji wirusów, europejskie izolaty SBWMV wykryte i opisane we Francji, zostały zaklasyfikowane jako wirus odglebowej mozaiki zbóż (Soil-borne cereal mosaic virus, SBCMV), w związku z tym wcześniej opublikowane metody diagnostyczne (Gitton i wsp. 1999; Clover i wsp. 2001) są niespecyficzne i nieprzydatne do wykrywania SBWMV. 


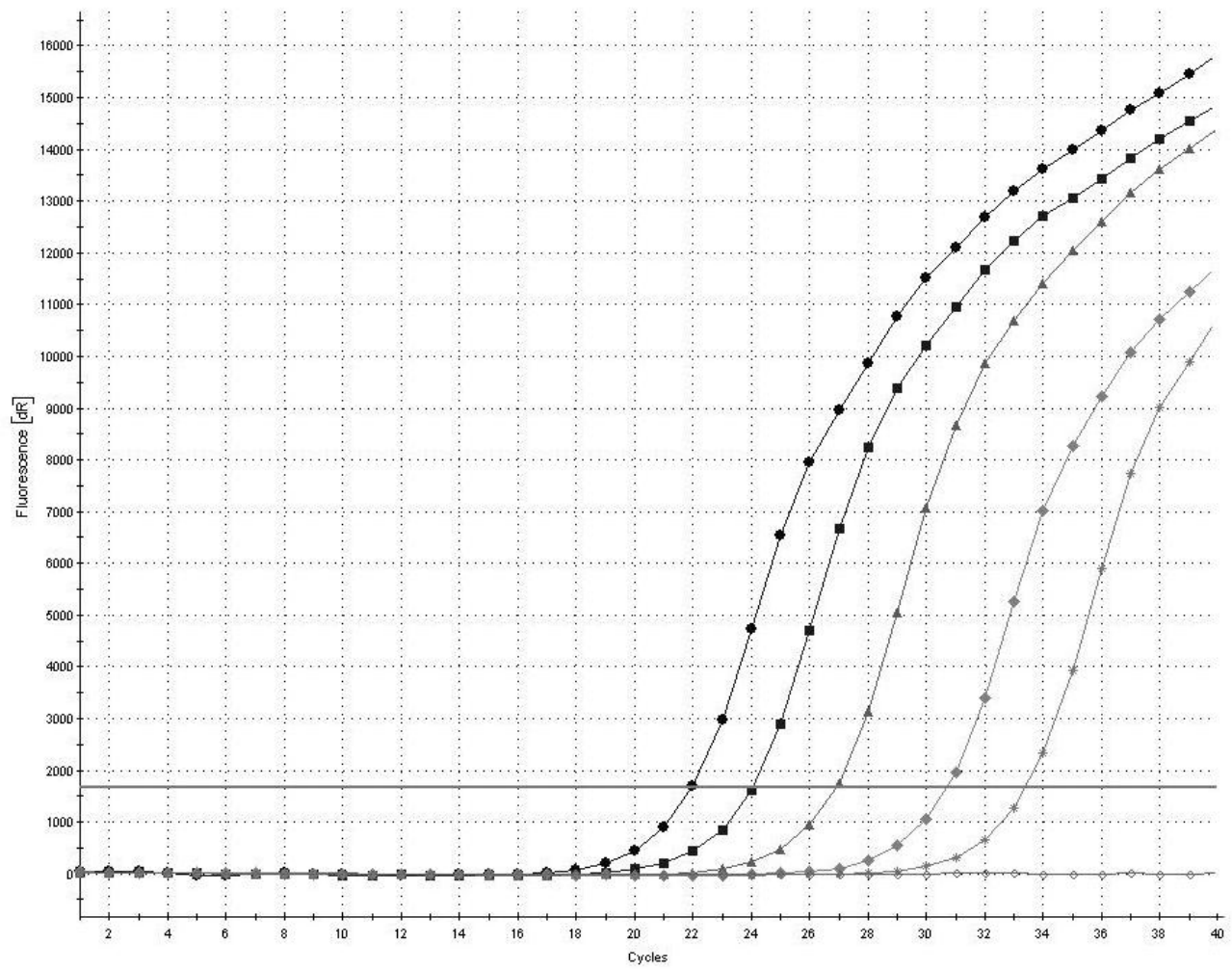

Rys. 1. Krzywe amplifikacji powstałe dla szeregu rozcieńczeń od $10^{0}$ do $10^{-4}$ dla izolatu SBWMV-De1

Fig. 1. Amplification curves prepared for 10 -fold serial dilutions from $10^{0}$ to $10^{-4}$ of SBWMV-De1 isolate

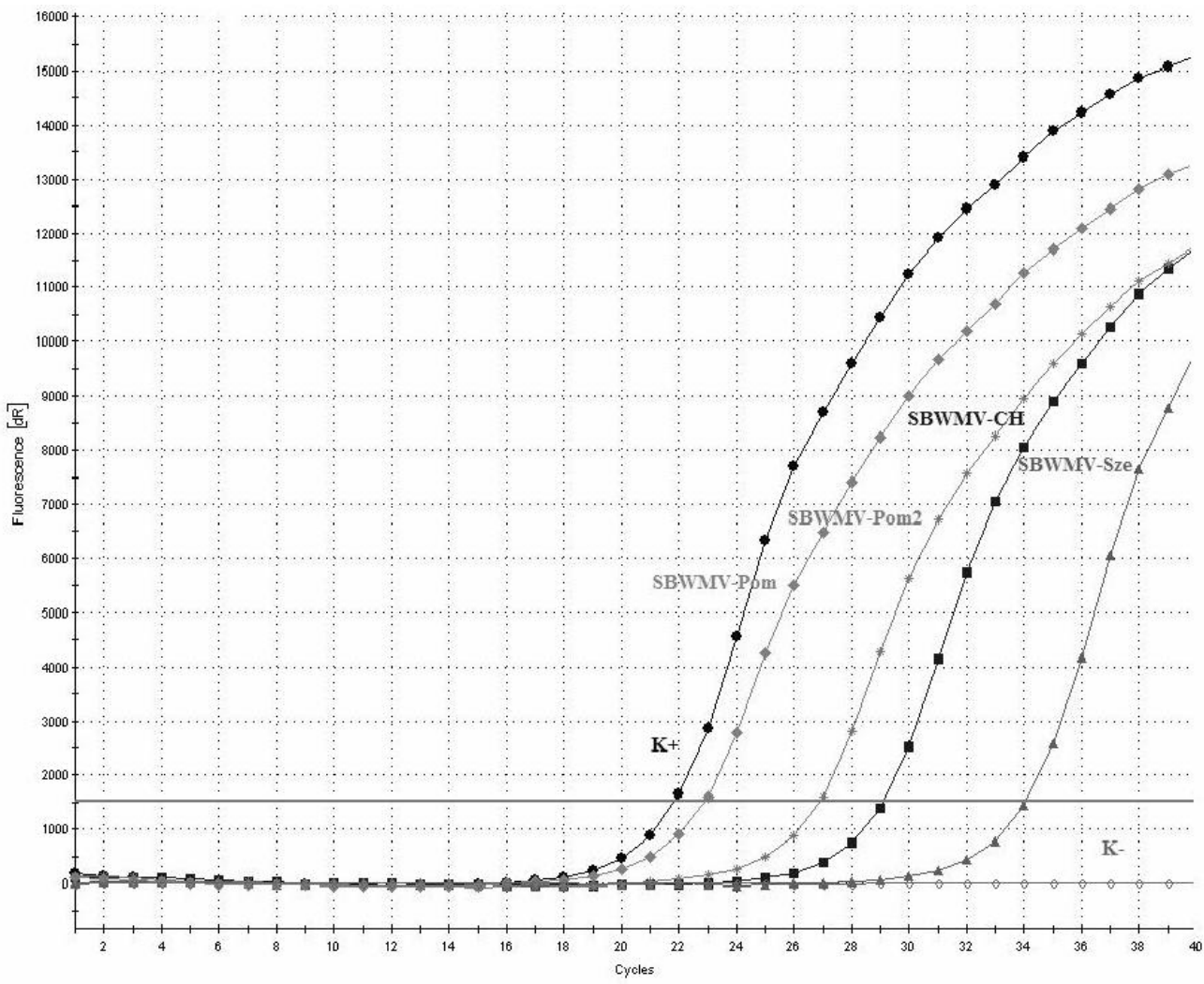

Rys. 2. Krzywe amplifikacji powstałe w reakcji real-time RT-PCR. K+ - kontrola pozytywna (SBWMV-De1); SBWMV-Pom, Pom2, $\mathrm{CH}$, Sze - polskie izolaty SBWMV; K- - kontrola negatywna (bez matrycy)

Fig. 2. Amplification curves obtained in real-time RT-PCR. K+ - positive control (SBWMV-De1); SBWMV-Pom, Pom2, CH, Sze Polish isolates, $\mathrm{K}$ - - negative control (without RNA) 


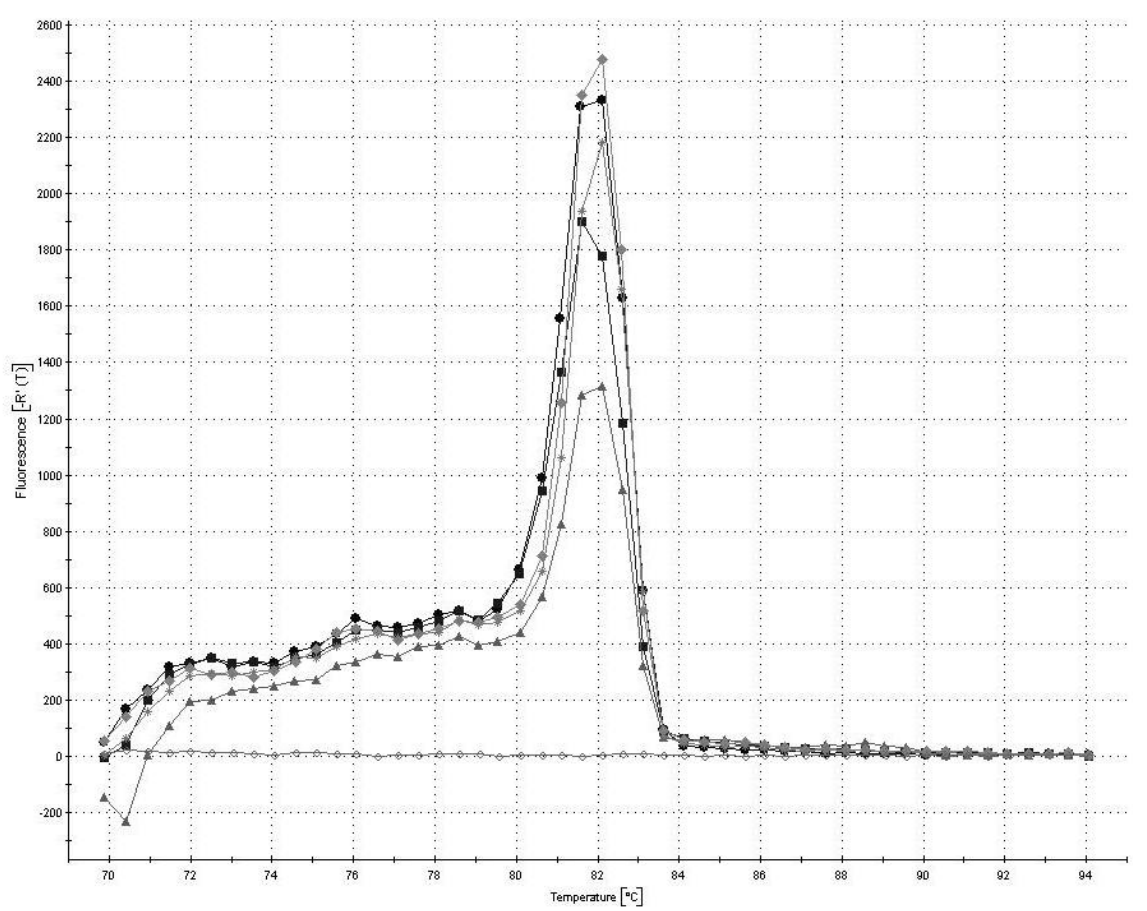

Rys. 3. Krzywa dysocjacji powstała w reakcji real-time RT-PCR Fig. 3. Dissociation curves obtained in real-time RT-PCR

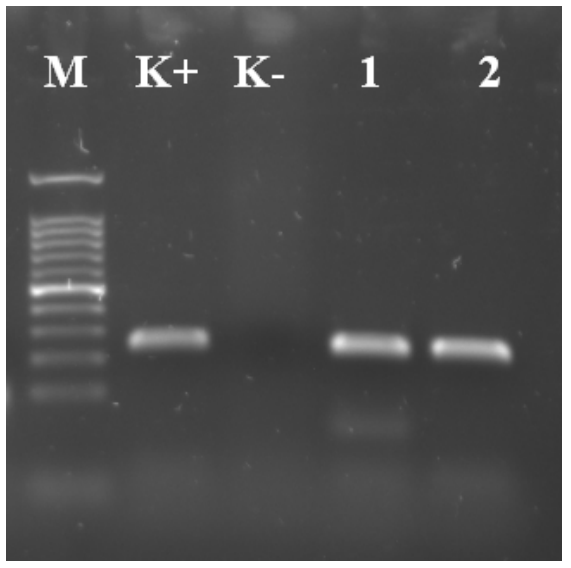

Rys. 4. Elektroforeza produktów real-time RT-PCR na $1 \%$ żelu agarozowym $\mathrm{M}$ - marker DNA pUC Mix Master 8 (Fermentas), $\mathrm{K}+-$ kontrola pozytywna, K- - kontrola negatywna, 12 - próby badane (SBWMV-Pom, SBWMV-Pom2)

Fig. 4. Electrophoresis mobility of realtime RT-PCR products on $1 \%$ agarose gel

$\mathrm{M}$ - marker DNA pUC Mix Master 8 (Fermentas), $\mathrm{K}+-$ positive control, K- - negative control , 1-2 studied samples (SBWMV-Pom, SBWMV-Pom2)

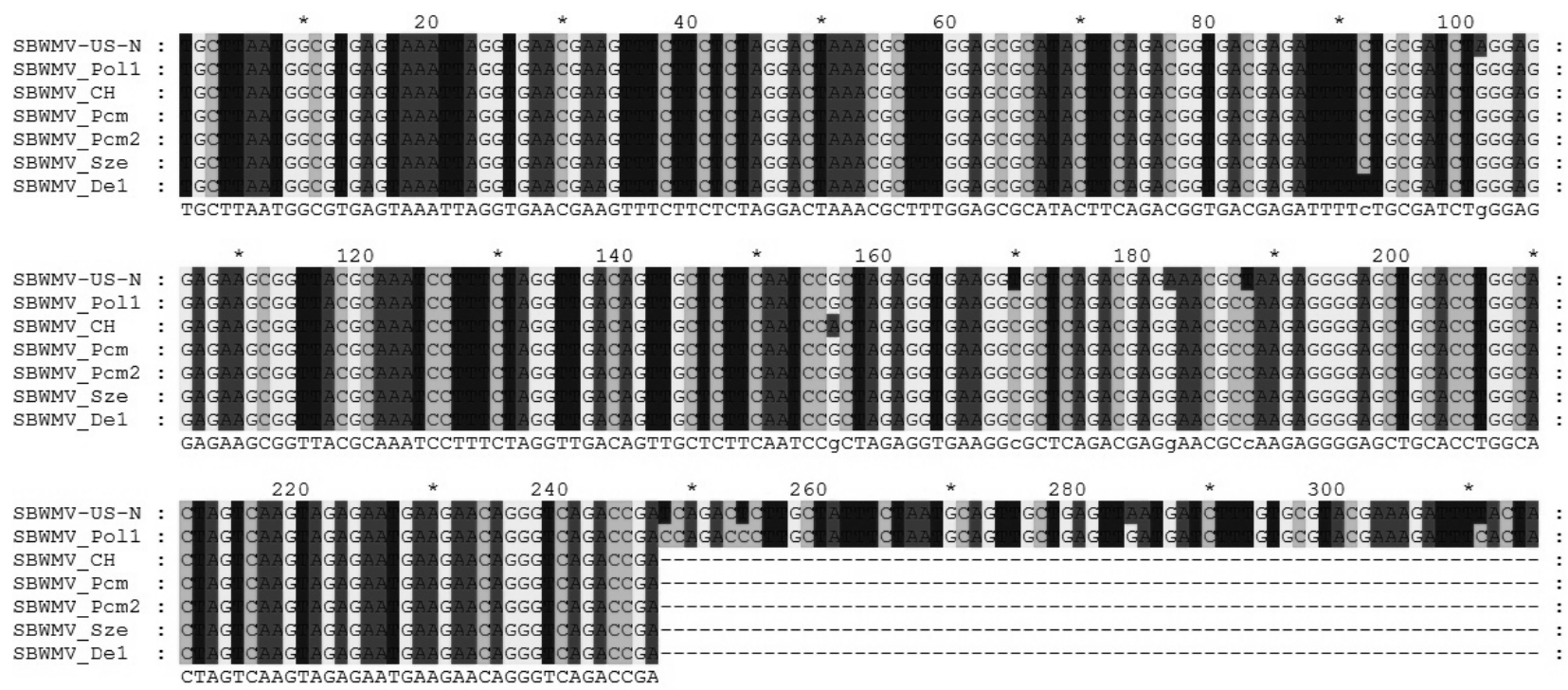

Rys. 5. Analiza sekwencji nukleotydów produktów real-time RT-PCR badanych izolatów SBWMV: US-Nebraska, Pol1, CH, Pom, Pom2, Sze i De1 w programie GenDoc

Fig. 5. Nucleotide sequence analysis of real-time RT-PCR products of studied SBWMV isolates: US-Nebraska, Pol1, CH, Pom, Pom2, Sze and De1 in GenDoc program

\section{Wioski / Conclusions}

1. Niska koncentracja cząstek SBWMV w soku badanych roślin powoduje trudności w diagnostyce $\mathrm{z}$ zastosowaniem testu DAS-ELISA oraz techniki RT-PCR.
2. Opracowana technika real-time RT-PCR może być wykorzystywana $\mathrm{w}$ rutynowej diagnostyce, a także do weryfikacji niejednoznacznych wyników testu DASELISA i techniki RT-PCR. 


\section{Podziękowanie / Ancknowledgements}

Autorki przekazują serdeczne podziękowania prof. Thomasowi Kühne z Julius Kühn-Institut Federal Research
Centre for Cultivated Plants za udostępnienie izolatu „Heddeshein”-Baden-Wüsthernberg SBWMV.

\section{Literatura / References}

Gitton F., Diao A., Ducrot O., Antoniw J.F., Adams M.J., Maraite H. 1999. A two-step multiplex RT-PCR method for simultaneous detection of soil-borne wheat mosaic virus and wheat spindle streak mosaic virus from France. Plant Pathology 48: 635-641.

Koenig R., Huth W. 2003. Natural infection of wheat by the type strain of Soil-borne wheat mosaic virus in a field of Southern Germany. European Journal of Plant Pathology 109: 191-193.

Price J.A., Smith J., Simmons A., Fellers J., Rush C.M. 2010. Multiplex real-time RT-PCR for detection of Wheat streak mosaic virus and Triticum mosaic virus. Journal of Virological Methods 165: 198-201.

Ratti C., Budge G., Ward L., Clover G., Rubies-Autonell C., Henry Ch. 2004. Detection and relative quantification of Soil-borne cereal mosaic virus (SBCMV) and Polymyxa graminis in winter wheat using real-time PCR (TaqMan $\left.{ }^{\circledR}\right)$. Journal of Virological Methods 122: 95-103.

Rosen S., Skaletski H.J. 2000. Primer3 on the WWW for general use and for biologist programmers. p. 365-386. In: "Bioinformatics Methods and Protocols: Method in Molecular Biology" (S. Krawetz, S. Misenes, eds). Humana Press, Totowa/New Jersey, 500 pp.

Trzmiel K., Jeżewska M., Zarzyńska A. 2012. First report of Soil-borne wheat mosaic virus (SBWMV) - infecting triticale in Poland. Journal of Phytopathology 160 (10): 614-616.

Verchot-Lubicz J. 2004. Soil-borne wheat mosaic. p. 585-588. In: "Viruses and Virus Diseases of Poaceae (Gramineae)" (H. Lapierre, P.A. Signoret, eds). Institut National de la Recherche Agronomique, Paris, 857 pp.

Zhang X., Zhou G., Wang X. 2010. Detection of wheat dwarf virus (WDV) in wheat and vector leafhopper (Psammotettix alienus Dahlb.) by real-time PCR. Journal of Virological Methods 169: 416-419. 